\title{
PENINGKATAN HASIL BELAJAR PAI MENGGUNAKAN METODE THE LEARNING CELL PADA MATERI MENCERITAKAN KISAH NABI
}

\author{
Marhadi \\ SDN 46 Rejang Lebong Kabupaten Rejang Lebong \\ marhadi388@gmail.com
}

\begin{abstract}
ABSTRAK
Penelitian ini bertujuan untuk mengetahui penerapan metode The Learning Cell pada mata pelajaran PAI materi menceritakan kisah Nabi dapat meningkatkan prestasi belajar siswa kelas V di SD Negeri 46 Rejang Lebong Kecamatan Selupu Rejang Kabupaten Rejang Lebong. Penelitian ini merupakan penelitian tindakan kelas (PTK) dengan jumlah subjek penelitian 16 orang siswa. Hasil penelitian menunjukkan pada siklus I nilai rata-rata siswa 71,25 meningkat sebesar 11,64. Siswa yang mendapat Nilai diatas KKM juga bertambah menjadi 9 anak atau $56,75 \%$ dari yang semula hanya 2 anak atau 87,5\%. Pada perbaikan siklus II ratarata nilai tes formatif siswa 82,81 meningkat 11,56 dari siklus yang I. Siswa yang mendapat nilai diatas batas nilai yang ditentukan (KKM) sebanyak 11 anak atau $68,75 \%$. Dapat disimpulkan, metode the learning cell dapat meningkatkan hasil belajar siswa pada materi menceritakan kisah nabi.
\end{abstract}

Kata Kunci: Prestasi Belajar, The Learning Cell.

\begin{abstract}
This study aims to determine the application of The Learning Cell method on subjects PAI material tells the story of the Prophet can improve the learning achievement of fifth grade students at SD Negeri 46 Rejang Lebong District Selupu Rejang Rejang Lebong District. This study is a classroom action research (CAR) with a total of 16 students. The results of the study showed that in the first cycle the average score of students was 71.25 which increased by 11.64. Students who scored above KKM also increased to 9 children or $56.75 \%$ from the original only 2 children or $87.5 \%$. In the second cycle improvement the average formative test scores of students were 82.81 increasing by 11.56 from the first cycle. Students who scored above the specified score (KKM) were 11 children or $68.75 \%$. It can be concluded, the learning cell method can improve student learning outcomes on material telling the story of the prophet.
\end{abstract}

Keywords: Learning Achievement, The Learning Cell.

\section{PENDAHULUAN}

Pembelajaran pendidikan agama Islam adalah kegiatan pembelajaran yang kompleks. Karena dalam pembelajaran pendidikan agama Islam selain berisi teori juga berisi tentang aturan praktik sehari-hari. Dalam pembelajaran ini, keberhasilan dalam menerapkan teori akan memberikan dampak positif terhadap 
pengamalan keberagamaan peserta didik. Dalam undang-undang Sisdiknas No 20 tahun 2003 diinstruksikan bahwa setiap jenjang pendidikan wajib menyelenggarakan pendidikan agama. Tujuan dari diajarkannya pendididikan agama ini adalah untuk membentuk manusia yang bertakwa dan bisa menghormati ajaran agama lain (Zakiah, 2011). Dalam praktiknya, pengajaran pendidikan agama Islam di sekolah juga berperan sebagai penanam nilai dan kepribadian luhur.

Adanya pandangan sebelah mata terhadap pelajaran agama Islam, selain itu kemrosotan nilai pendidikan agama Islam juga sering kali disebabkan karena metode mengajar yang kurang tepat. Kebanyakan guru masih menggunakan metode konvensional berupa ceramah dan pemberian tugas latihan. Dan bukan rahasia lagi bahwa metode ceramah dalam kegiatan pembelajaran dianggap metode kuno yang tidak efektif oleh para pakar pendidikan. Guru dalam proses pembelajaran sampai saat ini masih memposisikan dirinya sebagai pusat. Artinya segala aktifitas belajar harus sesuai dengan instruksi dan petunjuk guru. Siswa hanya dilibatkan dalam kegiatan pembelajaran setelah pelajaran selesai (Ismail, 2008)

Dalam proses belajar guru juga masih banyak yang hanya menggunakan satu buku acuan. Kebanyakan guru hanya menggunakan buku paket. Guru belum berani menggunakan sumber belajar lain. Potensi informasi yang ada dilingkungan sekitar yang begitu besar sering kali diabaikan oleh guru. Padahal sumber belajar yang langsung dapat dilihat dan diarasakan oleh siswa akan lebih membekas dan dipahami siswa. Hal ini terjadi pula di SDN 46 Rejang Lebong terutama di kelas VB. Dari 16 siswa kelas VB di SDN 46 Rejang Lebong hanya 3 anak yang memperoleh nilai diatas $\operatorname{KKM}(7,5)$. Dan setelah dilakukan penggalian terhadap akar penyebab belum tuntasnya belajar siswa ditemukan bahwa siswa tidak paham terhadap keterangan dari guru. Siswa juga sering bosan dan tidak dapat berkonsentrasi ketika guru memberikan penjelasan materi yang dipelajari.

Untuk itu perlu diupayakan pembelajaran yang dapat meningkatkan hasil belajar siswa. Dan upaya pembelajaran yang baru ini harus dapat mengaktifkan siswa sehingga siswa mampu menemukan sendiri pemahaman terhadap pelajaran agama Islam ini. Selain itu, metode pembelajaran yang baru ini harus dapat menumbuhkan semangat belajar siswa sehingga siswa menjadi lebih aktif dan lebih berkonsentrasi ketika belajar sehingga nilai hasil bajarnya akan meningkat.

Salah satu metode pembelajaran yang dapat digunakan yang sesuai dengan karakteristik siswa SD Negeri 46 Rejang Lebong adalah model pembelajaran kooperatif metode The Learning Cell. Dalam pembelajaran ini siswa dituntut untuk mandiri dalam menggali informasi tentang materi yang sedang dipelajari. Setelah itu siswa juga diarahkan untuk mengukur sendiri pemahamannya tentang materi yang dipelajari tersebut dengan saling bertanya jawab dengan teman pasangan belajarnya (Heryati, 2010) 
Dengan penerapan model pembelajaran ini, diharapkan siswa akan terbiasa aktif mencari informasi secara mandiri baik melalui buku maupun melalui lingkungan tempat siswa tinggal. Sehingga, selanjutnya siswa dapat menyelesaikan tugas maupun evaluasi dengan baik, baik tugas LKS maupun instrument tes lain yang diadakan diawal pelajaran (pre test) maupun diakhir pelajaran (post test) serta informasi yang diperoleh melalui lembar observasi. Dan akhirnya prestasi siswa ini juga akan naik sejalan dengan kesuksesan siswa dalam mengerjakan evaluasi dan tugas. Hal inilah yang menarik untuk diadakan penelitian dengan judul "Peningkatan Hasil Belajar PAI menggunakan Metode The Learning Cell pada Materi Menceritakan Kisah Nabi Siswa Kelas VB SDN 46 Rejang Lebong”.

\section{METODE PENELITIAN}

Penelitian tindakan kelas adalah upaya yang dilakukan unttuk mencermati kegiatan peserta didik dengan memberikan serangkaian tindakan yang disengaja untuk meningkatkan mutu peserta didik. Penelitian tindakan kelas yang dilaksanakan oleh peneliti merupakan penelitian kolaboratif antara peneliti sebagai pengajar pendidikan Agama Islam dan seorang guru kelas sebagai teman sejawat. Model penelitian yang peneliti gunakan adalah model PTK yang dikemukakan Kemmis dan Mc Taggart (Arikunto, 2010). Penelitian tidakan kelas ini terdiri dari dua siklus yang setiap siklusnya terdapat empat langkah, yaitu: rencana perbaikan, pelaksanaan perbaikan/ implementasi, pengamatan dan evaluasi serta refleksi.

Pada dasarnya, penelitian tindakan kelas atau classroom action research didesain untuk memecahkan masalah-masalah yang terjadi di dalam kelas dengan penerapan tindakan-tindakan tertentu secara langsung didalam kelas. Dalam penelitian tindakan kelas ini masalah yang dimaksud adalah rendahnya prestasi belajar siswa SD Negeri 46 Rejang Lebong. Alternatif yang digunakan untuk mengatasi masalah tersebut adalah dengan menerapkan metode The Learning Cell. Penerapan metode The Learning Cell yang peneliti terapkan dalam penelitian tindakan kelas ini tidak secara murni menggunakan prosedur sesuai yang dikembangkan pencetusnya Goldschmid akan tetapi dengan sedikit penyesuaian dengan latar alamiah kelas subjek penelitian.

Dalam penelitian ini peneliti menggunakan beberapa metode untuk menggali informasi yang dibutuhkan. Metode yang dipakai oleh peneliti untuk mendapatkan informasi tersebut antara lain Dokumentasi, pengamatan dan tes. Analisis data merupakan kegiatan mengubah data mentah menjadi data yang bermakna. Statistika deskriptif dapat digunakan untuk mengolah karakteristik data yang berkaitan dengan menjumlahkan, merata-rata, mencari titik tengah, mencari prosentase, sehingga data menjadi menarik, mudah dibaca, dan dapat diikuti alur fikirnya. Karena peneliti menggunakan data kwantitatif maka analisis yang peneliti gunakan yaitu presentase dengan rumus sebagai berikut; 


$$
\text { Nilai }=\frac{\text { skor } \text { yang dicapai }}{\text { skor maksimal }} \times 100 \%
$$

\section{HASIL PENELITIAN}

Perbaikan pembelajaran siklus I dilaksanakan dengan standar kompetensi "Menceritakan kisah Nabi" dan kompetensi dasar "Menceritakan kisah Nabi Musa as". Proses perbaikan tersebut diawali dengan apersepsi dan diakhiri dengan tes formatif. Hasil dari pelaksanaan tes formatif ini dianalisis untuk mengetahui keberhasilan dari pelaksanaan program perbaikan. Adapun hasil dari tes formatif siklus I diperoleh rata-rata sebesar 71,25

Perbaikan pembelajaran siklus II dilaksanakan dengan standar kompetensi "Menceritakan kisah Nabi" dan kompetensi dasar "Menceritakan kisah Nabi Isa as". Proses pebaikan tersebut diawali dengan apersepsi dan diakhiri dengan tes formatif. Fokus perbaikan pada siklus II ini adalah keaktifan siswa dalam mempelajari materi secara mandiri dan membuat pertanyaan yang memahamkan. Sebelum guru membagikan lembar tanya jawab, guru terlebih dahulu mengingatkan siswa agar ketika membuat pertanyaan diusahakan pertanyaan tersebut dapat difahami oleh teman-temannya dan menggunakan kalimat tanya. Dari tes formatif yang diadakan di akhir pertemuan Siklus II diperoleh data ratarata sebesar 82,81 .

Pada tahap pratindakan atau sebelum tindakan penelitian dilakukan diketahui bahwa dari 16 siswa kelas VB hanya ada 2 anak yang memperoleh nilai diatas KKM (75) atau hanya sebesar 12,5\%. Selebihnya, yaitu 14 anak atau 87,5 $\%$ memperoleh nilai di bawah KKM. Dan rata-rata klasikal atau rata-rata kelas pada tahap ini hanya pada taraf nilai 60,81 . Nilai ini tentu saja kurang dari nilai standar yang telah ditentukan oleh sekolah yaitu 75 .

\section{PEMBAHASAN}

Pada perbaikan pembelajaran siklus I terlihat bahwa setelah penerapan metode The Learning Cell hasil belajar siswa meningkat dibandingkan dengan sebelum metode ini di laksanakan. Pada tahap perbaikan siklus I diketahui dari 16 siswa kelas VB SD Negeri 46 Rejang Lebong 03, 9 anak atau sebesar 56,75\% telah memperoleh nilai di atas KKM. Walaupun 7 anak yang tersisa atau 43,75\% masih memperoleh nilai di bawah rata-rata namun, terlihat bahwa penerapan metode The Learning Cell telah menunjukkan keberhasilan.

Jumlah nilai tes pada tahap perbaikan siklus I mengalami peningkatan jika dibanding dengan jumlah nilai sebelum perbaikan pembelajaran diadakan. Dari jumlah nilai yang semula hanya 973 dengan rata-rata nilai kelas 60,81 meningkat menjadi 1140 dengan rata-rata 71,25. Dari data ini terlihat bahwa perbaikan siklus I menunjukkan kenaikan sebesar 167 pada jumlah nilai, 10,44 pada rata-rata kelas, 
dan $44,25 \%$ pada persentase ketuntasan klasikal. Walaupun angka ini belum memenuhi nilai standar yang ditentukan dan persentase ketuntasan klasikalnya belum mencapai $60 \%$, namun dapat dikatakan bahwa proses perbaikan siklus I telah berhasil. Perbaikan pembelajaran siklus II yang merupakan kelanjutan dari perbaikan siklus I memperlihatkan bahwa jumlah nilai yang semula 1140 pada siklus I meningkat sebesar 185 menjadi 1325. Nilai rata-rata kelas meningkat sebesar 11,56 menjadi 82,81. Persentase ketuntasan klasikal meningkat sebesar $12 \%$ dari yang semula $56,75 \%$ pada siklus I menjadi $68,75 \%$. Dengan tercapainya nilai rata-rata kelas 82,81 dengan persentase ketuntasan klasikal 68,75\% menunjukkan bahwa perbaikan siklus II sudah berhasil. Untuk lebih memperjelas paparan data hasil penelitian di atas, berikut ini disajikan diagram batang berdasar data-data yang telah terkumpul.

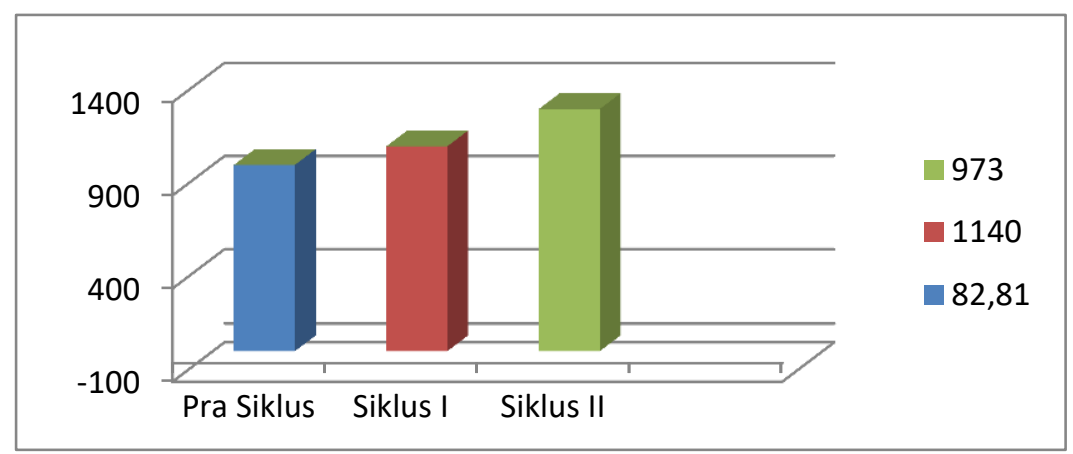

Grafik 1 Jumlah Nilai Sebelum dan Setelah Perbaikan

\section{SIMPULAN}

Dari seluruh kegiatan Penelitian tindakan kelas yang dilaksanakan di kelas VB SD Negeri 46 Rejang Lebong, dengan menggunakan metode The Learning Cell pada mata pelajaran PAI materi menceritakan kisah Nabi, dapat disimpulkan bahwa metode The Learning Cell dapat meningkatkan hasil belajar siswa kelas VB SD Negeri 46 Rejang Lebong. Hal ini ditunjukkan oleh meningkatnya nilai rerata hasil belajar siswa.

\section{DAFTAR PUSTAKA}

Arikunto, S. (2010). Prosedur

Penelitian Suatu Pendekatan Praktik. Jakarta: Rineka Cipta.

Darajat, Z, (2011). Metodik Khusus Pengajaran Agama Islam. Jakata: Bumi Aksara.

Departemen Agama Republik Indonesia.(1992). Al-Qur'an dan Terjemahan. Semarang: CV Asy-Syifa ${ }^{e e}$.

Heryati, Y. (2010). Media Pembelajaran. Jakarta Barat: Multi Kreasi Satu Delapan.

Ismail S.,M. (2008). Strategi Pembelajaran Agama Islam Berbasis PAIKEM. Semarang: Rasail Media Group. 